\title{
Solid Pseudopapillary Neoplasm of Pancreas; A Case Series and Review Literature
}

\author{
Babak Mirminachi ${ }^{1}$, Solmaz Farrokhzad ${ }^{1,2}$, Amir Houshang Sharifi ${ }^{1}$, Sepideh Nikfam ${ }^{1}$, \\ Arash Nikmanesh ${ }^{3}$, Reza Malekzadeh ${ }^{1}$, Akram Pourshams $^{1 *}$
}

1. Digestive Oncology Research Center, Digestive Disease Research Institute, Shariati Hospital, Tehran University of Medical Sciences, Tehran, Iran

2. Qazvin Health Center, Qazvin University of Medical Science, Qazvin, Iran

3. Department of Pathology, Masood Clinic, Tehran, Iran

\footnotetext{
* Corresponding Author:
}

Akram Pourshams, MD, MPH

Tehran University of Medical Sciences,

Digestive Oncology Research Center,

Digestive Disease Research Institute,

Shariati Hospital, Kargar Ave. Tehran

14117, Iran

Tel:+98 2182415104

Fax:+98 2182415400

Email: akrampourshams@gmail.com

Received: 02 Sep. 2015

Accepted: 12 Jan. 2016

\section{ABSTRACT}

\section{BACKGROUND}

Information regarding solid pseudopapillary neoplasm (SPN) of the pancreas is limited in Iran. We aimed to review the clinicocytopathological features and follow-up of patients with SPN of pancreas who were diagnosed in a single center in Iran.

\section{METHODS}

Seven patients with SPN of the pancreas were diagnosed during January 2010 to March 2015 at the Digestive Disease Research Institute of Tehran University of Medical Sciences. The patients were reviewed prospectively.

\section{RESULTS}

Six out of the 7 patients were female and the mean age of all the patients was 29.4 years ranging from 15 to 61 years. The most common clinical presentation was nonspecific abdominal pain $(\mathrm{N}=6)$. The tumors were located mostly in head and neck of the pancreas. SPN was diagnosed in all patients by fine needle aspiration through endosonography (EUS-FNA). All patients underwent surgery. Histological findings of surgical tissues were consistent with EUS-FNA. The postoperative follow-up period of about 14 months was uneventful.

\section{CONCLUSION}

SPN of the pancreas is a rare pancreatic tumor which affects primarily young women. EUS-guided FNA could play an important role in preoperative diagnosis of SPN of the pancreas.

\section{KEYWORDS}

Solid pseudopapillary neoplasm, Pancreas, Immunohistochemistry

Please cite this paper as:

Mirminachi B, Farrokhzad S, Sharifi AH, Nikfam S, Nikmanesh A, Malekzadeh R, Pourshams A. Solid Pseudopapillary Neoplasm of Pancreas; A Case Series and Review Literature. Middle East J Dig Dis 2016;8:102-108. DOI : 10.15171/mejdd.2016.14

\section{INTRODUCTION}

Solid pseudopapillary neoplasm (SPN) is a rare pancreatic tumors, characterized by low malignant potential and strong female predilection. SPN was first described in 1959. This tumor had several names including Frantz's tumor, solid and papillary tumor, solid-cystic tumor, papil- 
lary cystic tumor, and solid and papillary epithelial neoplasm until 1996 when World Health Organization defined it as solid pseudopapillary tumor of the pancreas. It previously accounted for $0.2-2.7 \%$ of all exocrine tumors of the pancreas. ${ }^{1-3}$ However, due to the recent advantages in medical imaging, the incidence of SPN has increased to $5-6 \%$ of all diagnosed pancreatic tumors. SPN is diagnosed much more common in children than in adults consisting of $26 \%$ of pancreatic tumors. ${ }^{4}$ SPN shows a strong female predilection, $90 \%$ of them arising in adolescent and young adult women. ${ }^{5}$ Few cases have been reported in men and children. ${ }^{6-8}$ The overall mortality rate of SPN is about $2 \%$ and recurrence occurred in almost $10-15 \%$ of patients after resection. ${ }^{9}$

The etiopathogenesis of SPN has not been fully understood. The predominant occurrence of SPN in young women at the beginning of the reproductive period along with the presence of progesterone receptors, indicate the role of female hormones in the growth of this tumor. ${ }^{10}$ This idea has been supported by the fact that genital ridges are closed to the pancreatic anlage during embryogenesis. ${ }^{10-12}$ Chromosomal abnormalities are the other mechanism that may have an etiological role in the development of this neoplasm. Some studies suggested that mutation in B-catenin, could play a major role in the tumorogenesis of SPN. ${ }^{13}$ According to immunohistochemical and electron microscopic studies, it has been suggested that these tumors originate from undifferentiated pluripotent emberyonal cells. ${ }^{14}$

Herein, we describe the clinical, radiological and cytopathological features of solid pseudopapillary tumor of the pancreas (SPNP) diagnosed by endoscopic ultrasound-guided (EUS-guided) fine-needle aspiration (FNA) and review of relevant literature.

\section{MATERIALS AND METHODS}

Patients with final diagnosis of pseudo papillary tumor who referred for EUS to Shariati Hospital, affiliated to Tehran University of Medical Sciences from November 2010 to March 2015 were enrolled. The demographic, clinical and pathological features of all patients were recorded in the Digestive Disease Research Institute. The database included age, sex, associated symptoms, laboratory data, tumor size and location, arterial and perineural invasion, distant metastasis, lymphadenopathy, operative data, and postoperative complications.

The first diagnosis in all patients was made by EUS-FNA cytology samples and finally by surgical tissue. EUS was performed using conscious sedation and linear array Pentax echoendoscopes. The endosonographer inserted a 22 gauge needle into the target lesion and aspirated samples by three passes, almost without applying suction. Aspiration of lesions located in the head of the pancreas or uncinate process was done through the transduodenal approach and lesions in the body and tail of the pancreas through the transgastric route. All samples were enough for cytologic evaluation and there was no need to repeat FNA in any patient. Details of fine-needle aspiration and surgical pathology results were recorded.

Diagnosis of SPNP was confirmed using immunohistochemical (IHC) staining. IHC was done on FNA cell block samples using Dako REAL ${ }^{\mathrm{TM}}$ En Vision ${ }^{\mathrm{TM}}$ Detection System, Peroxidase/DAB ${ }^{+}$, Rabbit/Mouse. After surgical operation, all specimens were sent for pathological analysis as well. The hematoxylin and eosin ( $\mathrm{H}$ and $\mathrm{E}$ ) stained sections of all FNA and surgical samples were reviewed by an expert pathologist to confirm the diagnosis. The IHC markers (primary antibodies) used in the analysis, included vimentin (clone; v9), pan cytokeratin (CK) (clone; AE1 and AE3), $\beta$-catenin (clone; Ncl$\beta$-catenin), CD10 (clone; 56c6), progesterone receptor (PR) (clone; PR88), Synaptophysin (clone; 27G12), and chromogranin A (clone; LK2H10). The patients were followed up through out-patient visits or by telephone interviews. The last followup was on March 2015. All of the patients underwent a variety of radiological examinations for preoperative diagnosis including transabdominal ultrasonography, computed tomography (CT) and magnetic resonance imaging (MRI).

The study was approved by the Ethics committee and Institutional Review Board of the Digestive Disease Research Institute of Tehran University of Medical Sciences, Tehran, Iran. 
Table 1: Clinical and pathological features of patients

\begin{tabular}{|c|c|c|c|c|c|c|c|}
\hline $\begin{array}{l}\text { Case } \\
\text { No. }\end{array}$ & $\begin{array}{l}\text { Age } \\
\text { (year) }\end{array}$ & Sex & Symptoms & $\begin{array}{l}\text { Tumor } \\
\text { location }\end{array}$ & $\begin{array}{l}\text { Tumor size } \\
(\mathbf{m m})\end{array}$ & $\begin{array}{l}\text { Post-operative } \\
\text { complication }\end{array}$ & IHC findings \\
\hline 1 & 24 & $\mathrm{~F}$ & $\begin{array}{l}\text { Abdominal discomfort, } \\
\text { bloating, nausea, } \\
\text { vomiting and early } \\
\text { satiety }\end{array}$ & Head & $19 \times 16$ & Uneventful & $\begin{array}{l}\text { Strongly positive for Vimentin } \\
\text { Positive for Synaptophysin, PR snd CD10 } \\
\text { Weakly positive for Chromogranin }\end{array}$ \\
\hline 2 & 19 & $\mathrm{~F}$ & Abdominal pain & Neck & $47 \times 34$ & Uneventful & Positive for Vimentin, CD10, and PR \\
\hline 3 & 21 & $\mathrm{~F}$ & $\begin{array}{l}\text { Epigastric pain, } \\
\text { nausea, vomiting, } \\
\text { early satiety and } \\
\text { itching }\end{array}$ & Head & $60 \times 31$ & $\begin{array}{l}\text { Abdominal } \\
\text { pain }\end{array}$ & $\begin{array}{l}\text { Positive for Vimentin, CD10, NSE and PR } \\
\text { Weakly positive for Pan CK }\end{array}$ \\
\hline 4 & 61 & M & Asymptomatic & Body & $40 \times 30$ & Uneventful & $\begin{array}{l}\text { Positive for NSE, Chromogranin, } \\
\text { Synaptophysin } \\
\text { Weakly positive for Pan CK and PR }\end{array}$ \\
\hline 5 & 20 & $\mathrm{~F}$ & $\begin{array}{l}\text { Bloating, abdominal } \\
\text { pain }\end{array}$ & Neck & $12 \times 10$ & Uneventful & $\begin{array}{l}\text { Positive reaction to Vimentin } \\
\text { Weakly positive for CD10 }\end{array}$ \\
\hline 6 & 15 & $\mathrm{~F}$ & Abdominal pain & $\begin{array}{l}\text { Body and } \\
\text { tail }\end{array}$ & $60 \times 58$ & Uneventful & $\begin{array}{l}\text { Strongly positive for B-catenin and } \\
\text { Vimentin Weakly positive for Synap- } \\
\text { tophysin, CD10 and PR }\end{array}$ \\
\hline 7 & 40 & $\mathrm{~F}$ & $\begin{array}{l}\text { Asthenia, abdomi- } \\
\text { nal pain, nausea and } \\
\text { vomiting }\end{array}$ & Tail & $60 \times 57$ & Uneventful & $\begin{array}{l}\text { Positive for Vimentin, and PR, } \\
\text { Weakly positive for CD10 }\end{array}$ \\
\hline
\end{tabular}

NSE: Neuron specific enolase, PR: Progesterone receptor, Pan CK: Pan cytokeratin

Data were analyzed using SPSS software, version 20 (IBM, New York, USA).

\section{RESULTS}

Seven patients underwent surgical treatment for SPN of the pancreas during the study period. Preoperative diagnosis was made by EUS in all patients. Of these patients, $6(85.7 \%)$ were female. The mean \pm SD age of diagnosis was $29.4 \pm 17.2$ ranging from 15 to 61 years. Six out of 7 patients presented with nonspecific abdominal pain. In one patient, the tumor was incidentally identified by CT. The level of serum amylase and tumor markers was within the normal range in all patients except in one. The tumor cells were mostly positive for vimentin, PR and CD10, each in 6 cases. Synaptophysin was positive in 3 patients, followed by NSE and cytokeratin, each in 2 patients. $\beta$-catenin was only positive in 1 patient. Patient characteristics are summarized in table 1 .

\section{Surgical treatment}

All patients underwent surgical treatment. The most common location of the tumor was the head and neck of the pancreas, each in $2(28.5 \%)$ patients, followed by the body, tail and both the body and tail, each in one patient. The mean diameter of the tumor was $42.5 \mathrm{~mm}$ (range: 12-60 $\mathrm{mm}$ ). Two patients had perineural invasion; however, none of the patients showed distant metastasis. Four patients with lesion in the head or neck underwent pancreaticoduodenectomy. The other three patients with lesions in the body and/or in the tail underwent distal pancreatectomy. There were no perioperative surgical deaths or perioperative complications.

\section{EUS findings}

A mixed solid and cystic appearance was identified in three patients, and others had predominantly solid appearance. The margin of the masses was well defined in all the patients. There was no evidence of vascular, or lymph node involvement.

\section{DISCUSSION}

The most common presenting symptoms of SPNs are abdominal pain followed by increased abdominal girth, poor appetite and nausea resulting from tumor compression on the adjacent organs 
and a palpable mass. ${ }^{15}$ Although almost $30 \%$ of patients are completely asymptomatic and discovered incidentally during routine clinical examination or diagnostic imaging procedures, some patients $(8 \%)$ present with acute abdomen as a result of abdominal blunt trauma or spontaneous rupture of the capsule. ${ }^{16}$ Clinical presentations of our patients included abdominal pain, nausea and vomiting, weight loss, bloating and feeling of fullness.

It has a strong female preponderance with femalemale ratio of 5:1.9 $9^{17}$ and up to $10: 1 .^{3}$ Male patients presented much later compared with women (mean age: 31 years). ${ }^{18,19}$

The diagnosis of SPN has increased during the recent years due to advances in diagnostic imaging techniques. However, clinical and radiological findings are insufficient for reaching a definite diagnosis and tissue sampling should always be considered. EUS-FNA needle aspiration and cytology is the best technique for preoperative diagnosis of SPN and less invasiveness than surgical procedures. EUS-FNA is increasingly using for identifying the tumor over the recent years, however it still constitutes fewer than $5 \%$ of performed imaging. SPN lesions have been shown as well-circumscribed, hypoecho, heterogenous solid and cystic masses by EUS. EUS-FNA is significantly more effective than CT in differentiating neoplastic from non-neoplastic, along the identifying malignant pancreatic cysts. ${ }^{20}$ Furthermore, immunohistochemical staining and mutation analysis of beta catenin gene are helpful in distinguishing SPN from other pancreatic tumors. ${ }^{21}$

Complete surgical resection is the mainstay of treatment in all patients with SPN even in the presence of local invasion or distant metastasis. The most common surgical procedures performed for pancreatic SPN are distal pancreatectomy and pancreaticoduodenectomy (Whipple surgery). Local invasion and distant metastasis were reported in 5\% and $6 \%$ of SPN patients, respectively. ${ }^{22}$ The most frequent sites affected by metastases include the liver (28\%), wall of vena cava (27\%) and the spleen (17\%). Duodenum, omentum, colon, and lung are the other preference location of metastases. ${ }^{23}$ In- vasion to regional lymph nodes has been rarely reported which is consistent with our series. ${ }^{24,25}$ The efficacy of non-surgical approaches including chemotherapy and radiotherapy has not been proven. ${ }^{26,27}$ The prognosis of SPN is favorable, even in the presence of metastases or invasion to other organs. ${ }^{28-30}$ Considering the fact that the 5-year survival rate of SPN is $94-97 \%$, it is very important to differentiate it from other pancreatic lesions. However, if metastatic lesions are impossible to be removed, long-term survival is undeterminable. There are several reports of liver transplantation in patients with unresectable hepatic metastases. ${ }^{31}$

According to the largest report of patients with SPN, pancreatic tail and the head of pancreas are the most common localizations of the tumor followed by pancreatic body, body and tail, head and body, neck and the uncinate process of the pancreas. ${ }^{5}$ However, in this series, only one of our patients had tumor in the tail region and most of the tumors were located in the pancreatic head and neck. In our series, perineural invasion was found in two patients. Vimentin was positive in $4(57 \%)$ of the patients. Our small sample size did not allow us to compare different tumor characteristics with the sex of the patients. Lymph node metastases were not found in none of the patients in this series which is consistent with other reports. The mean follow-up period of our patients was 14 months (7-30 months) which is short for giving a comprehensive opinion on recurrence rate. In previous studies, SPN have a mean diameter of $6.08 \mathrm{Cm}$ (range 0.5 to $34.5 \mathrm{Cm}$ ). Metastasis or local recurrence rate of SPNP in patients treated by radical surgical excision is $9 \%-15 \% .^{22,32}$ There was no evidence of local or distant metastases in our patients. As we presented in our series, there was no association between SPNP and laboratory test results including serum tumor markers. ${ }^{33,34}$

The data regarding prognostic factors for malignant transformation of SPN are controversial. Factors that can be useful in predicting the malignant potential of the tumor are perineural and vascular invasion, lymph node involvement and deep invasion of surrounding tissues..$^{15}$ The morphological appearance is not a good predictor of clinical behavior of these 
Table 2: Comparison of clinical characteristics and outcome of SPN patients between present study and worldwide studies

\begin{tabular}{|c|c|c|c|c|c|c|c|}
\hline Study & $\begin{array}{l}\text { Number } \\
\text { of cases }\end{array}$ & $\begin{array}{l}\text { Age, mean } \\
\text { (range) year }\end{array}$ & $\begin{array}{c}\text { Sex ratio } \\
(\mathbf{F} / \mathbf{M})\end{array}$ & $\begin{array}{l}\text { Tumor size, mean } \\
\text { (range) } \mathrm{Cm}\end{array}$ & $\begin{array}{l}\text { Follow-up, mean } \\
\text { (range) month }\end{array}$ & $\begin{array}{l}\text { No.distant } \\
\text { meatastases }\end{array}$ & Survival, \% \\
\hline Salvia et al. ${ }^{33}$ & 31 & $34(7-56)$ & $27 / 4$ & $5.4(2-20)$ & $58(12-229)$ & 0 & 100 \\
\hline Tipton et al. ${ }^{26}$ & 14 & $30(15-57)$ & $13 / 1$ & 7 (4-16) & $88(3-240)$ & 2 & 100 \\
\hline Goh et al. ${ }^{24}$ & 16 & $30(14-53)$ & $15 / 1$ & $9.5(5-24)$ & $67(3-186)$ & 0 & 100 \\
\hline Yang et al. ${ }^{41}$ & 26 & $32(15-64)$ & $22 / 4$ & $6.25(2-15)$ & $33(3-69)$ & 2 & 96.2 \\
\hline Guo et al. ${ }^{42}$ & 24 & $31(11-61)$ & $23 / 1$ & $7.5(2-26)$ & $68(4-109)$ & 2 & 95.8 \\
\hline Zhang et al. ${ }^{43}$ & 9 & $30(14-68)$ & $8 / 1$ & $5.4(2-10.5)$ & 30 (NA) & 2 & 88.8 \\
\hline Vassos et al. ${ }^{44}$ & 4 & $24.5(15-42)$ & $4 / 0$ & $5.5(1-16)$ & $40(24-57)$ & 0 & 100 \\
\hline Present study & 7 & $29.7(15-61)$ & $6 / 1$ & $4.03(1.2-6)$ & $14(7-30)$ & 0 & 100 \\
\hline
\end{tabular}

tumors; SPN with subtle histological malignant appearance can show local invasion to adjacent structures. ${ }^{30}$

Several studies indicated that male sex, large tumor size $(>5 \mathrm{Cm})$, and tumor necrosis could predict malignant transformation. ${ }^{35}$ However, most of the studies do not report any association between age and tumor location with malignant potential of SPN. ${ }^{36}$

The clinical features and outcome of our patients were compared with recent reports from other countries in table 2 . There are similar characteristics among these reports especially regarding age and female predominance.

In our study, IHC analysis showed strong positivity for vimentin, CD10, and PR. These findings are consistent with previous studies that reported positivity for vimentin in $100 \%$ and $70 \%$ of cases, respectively. ${ }^{37,38}$ Tumor cells of SPN showed strong positivity for CD10 in two previous studies, ${ }^{39}, 40 \mathrm{In}$ the present series, PR was positive in 6 out of 7 patients. Machado et al, ${ }^{25}$ reported PR positivity in $80 \%$ of cases and the percentage of PR positivity was $64.5 \%$ in a study by Uppin et al. ${ }^{37}$ Taken together, the frequent expression of PR and strong female predilection of SPN indicate the importance of hormone dependency in the pathogenesis of this tumor.

\section{CONCLUSION}

SPN is a rare tumor mostly seen in young women. SPN of the pancreas have an excellent prognosis. EUS-guided FNA with preparing cell block from the aspiration and using IHC with relevant markers are a very helpful techniques for preoperative diagnosis of SPN.

\section{CONFLICT OF INTEREST}

The authors declare no conflict of interest related tothis work.

\section{REFERENCES}

1. Madan AK, Weldon CB, Long WP, Johnson D, Raafat A. Solid and papillary epithelial neoplasm of the pancreas. J Surg Oncol 2004 15;85:193-8. doi: 10.1002/jso.20019

2. Martin RC, Klimstra DS, Brennan MF, Conlon KC. Solidpseudopapillary tumor of the pancreas: a surgical enigma? Ann Surg Oncol 2002;9:35-40.

3. Mulkeen AL, Yoo PS, Cha C. Less common neoplasms of the pancreas. World J Gastroenterol 2006 28;12:3180-5.

4. Grosfeld JL, Vane DW, Rescorla FJ, McGuire W, West KW. Pancreatic tumors in childhood: analysis of 13 cases. $J$ Pediatr Surg 1990;25:1057-62. doi: 10.1016/00223468(90)90218-X

5. Papavramidis T, Papavramidis S. Solid pseudopapillary tumors of the pancreas: review of 718 patients reported in English literature. $J$ Am Coll Surg 2005;200:965-72. doi: 10.1016/j.jamcollsurg.2005.02.011

6. Nadler EP, Novikov A, Landzberg BR, Pochapin MB, Centeno B, Fahey TJ, et al. The use of endoscopic ultrasound in the diagnosis of solid pseudopapillary tumors of the pancreas in children. J Pediatr Surg 2002;37:1370-3. doi: 10.1053/jpsu.2002.35028

7. Casanova M, Collini P, Ferrari A, Cecchetto G, Dall'Igna P, Mazzaferro V. Solid-pseudopapillary tumor of the pancreas (Frantz tumor) in children. Med Pediatr Oncol 2003;41:74-6. doi: $10.1002 / \mathrm{mpo} .10289$

8. Rebhandl W, Felberbauer FX, Puig S, Paya K, Hochschorner S, Barlan M, et al. Solid-pseudopapillary tumor of the pancreas (Frantz tumor) in children: report of four cases and review of the literature. J Surg Oncol 2001;76:289-96. doi: $10.1002 /$ jso. 1048

9. Geers C, Moulin P, Gigot JF, Weynand B, Deprez P, Rahier $\mathrm{J}$, et al. Solid and pseudopapillary tumor of the pancreas-review and new insights into pathogenesis. Am J Surg Pathol 2006;30:1243-9. doi:10.1097/01.pas.0000213311.28682.b2 
10. Kosmahl M, Seada LS, Janig U, Harms D, Kloppel G. Solid-pseudopapillary tumor of the pancreas: its origin revisited. Virchows Arch 2000;436:473-80.

11. Chávez M, Pérez A, Vargas G, Verona R, Puga R. Solid Pseudopapillary Neoplasm of Pancreas; A Case Series and Review Literature. Rev Gastroenterol Peru 1996;16:64-71.

12. Nishihara K, Tsuneyoshi M, Ohshima A, Yamaguchi K. Papillary cystic tumor of the pancreas. Is it a hormonedependent neoplasm? Pathol Res Pract 1993;189:521-6. doi:10.1016/S0344-0338(11)80359-6

13. Tanaka Y, Kato K, Notohara K, Hojo H, Ijiri R, Miyake $\mathrm{T}$, et al. Frequent beta-catenin mutation and cytoplasmic/ nuclear accumulation in pancreatic solid-pseudopapillary neoplasm. Cancer Res 2001;61:8401-4.

14. Canzonieri V, Berretta M, Buonadonna A, Libra M, Vasquez E, Barbagallo E, et al. Solid pseudopapillary tumour of the pancreas. Lancet Oncol 2003;4:255-6. doi: 10.1016/ S1470-2045(03)01038-6

15. Igbinosa O. Pseudopapillary tumor of the pancreas. An algorithmic approach. JOP 2011;12:262-5.

16. Mao C, Guvendi M, Domenico DR, Kim K, Thomford NR, Howard JM. Papillary cystic and solid tumors of the pancreas: a pancreatic embryonic tumor? Studies of three cases and cumulative review of the world's literature. Surgery 1995;118:821-8. doi: 10.1016/S0039-6060(05)80271-5

17. Choi JY, Kim MJ, Kim JH, Kim SH, Lim JS, Oh YT, et al. Solid pseudopapillary tumor of the pancreas: typical and atypical manifestations. AJR Am J Roentgenol 2006;187:W178-86.

18. Frago R, Fabregat J, Jorba R, Garcia-Borobia F, Altet J, Serrano MT, et al. Solid pseudopapillary tumors of the pancreas: diagnosis and curative treatment. Rev Esp Enferm Dig 2006;98:809-16.

19. Bouassida M, Mighri MM, Bacha D, Chtourou MF, Touinsi H, Azzouz MM, et al. Solid pseudopapillary neoplasm of the pancreas in an old man: age does not matter. Pan Afr Med J 2012;13:8.

20. Law JK, Stoita A, Wever W, Gleeson FC, Dries AM, Blackford $\mathrm{A}$, et al. Endoscopic ultrasound-guided fine needle aspiration improves the pre-operative diagnostic yield of solid-pseudopapillary neoplasm of the pancreas: an international multicenter case series (with video). Surg Endosc 2014;28:2592-8. doi: 10.1007/s00464-014-3508-8

21. Abraham SC, Klimstra DS, Wilentz RE, Yeo CJ, Conlon $\mathrm{K}$, Brennan M, et al. Solid-pseudopapillary tumors of the pancreas are genetically distinct from pancreatic ductal adenocarcinomas and almost always harbor beta-catenin mutations. Am J Pathol 2002;160:1361-9. doi: 10.1016/ S0002-9440(10)62563-1

22. Gonzalez-Campora R, Rios Martin JJ, Villar Rodriguez JL, Otal Salaverri C, Hevia Vazquez A, Valladolid JM, et al. Papillary cystic neoplasm of the pancreas with liver metastasis coexisting with thyroid papillary carcinoma. Arch Pathol Lab Med 1995;119:268-73.
23. Tang LH, Aydin H, Brennan MF, Klimstra DS. Clinically aggressive solid pseudopapillary tumors of the pancreas: a report of two cases with components of undifferentiated carcinoma and a comparative clinicopathologic analysis of 34 conventional cases. Am J Surg Pathol 2005;29:512-9.

24. Goh BK, Tan YM, Cheow PC, Chung AY, Chow PK, Wong WK, et al. Solid pseudopapillary neoplasms of the pancreas: an updated experience. J Surg Oncol 2007;95:640-4. doi: $10.1002 /$ jso. 20735

25. Machado MC, Machado MA, Bacchella T, Jukemura J, Almeida JL, Cunha JE. Solid pseudopapillary neoplasm of the pancreas: distinct patterns of onset, diagnosis, and prognosis for male versus female patients. Surgery 2008;143:2934. doi: 10.1016/j.surg.2007.07.030

26. Tipton SG, Smyrk TC, Sarr MG, Thompson GB. Malignant potential of solid pseudopapillary neoplasm of the pancreas. Br J Surg 2006;93:733-7. doi: 10.1002/bjs.5334

27. Maffuz A, Bustamante Fde T, Silva JA, Torres-Vargas S. Preoperative gemcitabine for unresectable, solid pseudopapillary tumour of the pancreas. Lancet Oncol 2005;6:185-6. doi: 10.1016/S1470-2045(05)01770-5

28. Gedaly R, Toledano A, Millan G, Essenfeld H, Zambrano VJ. Treatment of liver metastases from a solid pseudopapillary tumor of the pancreas. J Hepatobiliary Pancreat Surg 2006;13:587-90.

29. Eder F, Schulz HU, Rocken C, Lippert H. Solid-pseudopapillary tumor of the pancreatic tail. World J Gastroenterol 2005;11:4117-9. doi: 10.3748/wjg.v11.i26.4117

30. Coleman KM, Doherty MC, Bigler SA. Solid-pseudopapillary tumor of the pancreas. Radiographics 2003;23:16448. doi: $10.1148 / \mathrm{rg} .236035006$

31. Sumida W, Kaneko K, Tainaka T, Ono Y, Kiuchi T, Ando $\mathrm{H}$. Liver transplantation for multiple liver metastases from solid pseudopapillary tumor of the pancreas. J Pediatr Surg 2007;42:e27-31. doi: 10.1016/j.jpedsurg.2007.08.056

32. Maitra A, Weinberg AG, Schneider N, Patterson K. Detection of $\mathrm{t}(11 ; 22)(\mathrm{q} 24 ; \mathrm{q} 12)$ translocation and EWS-FLI-1 fusion transcript in a case of solid pseudopapillary tumor of the pancreas. Pediatr Dev Pathol 2000;3:603-5.

33. Salvia R, Bassi C, Festa L, Falconi M, Crippa S, Butturini $\mathrm{G}$, et al. Clinical and biological behavior of pancreatic solid pseudopapillary tumors: report on 31 consecutive patients. J Surg Oncol 2007;95:304-10.

34. Yoon DY, Hines OJ, Bilchik AJ, Lewin K, Cortina G, Reber HA. Solid and papillary epithelial neoplasms of the pancreas: aggressive resection for cure. Am Surg 2001;67:1195-9.

35. Kang CM, Kim KS, Choi JS, Kim H, Lee WJ, Kim BR. Solid pseudopapillary tumor of the pancreas suggesting malignant potential. Pancreas 2006;32:276-80. doi: 10.1097/01.mpa.0000202956.41106.8a

36. Lee SE, Jang JY, Hwang DW, Park KW, Kim SW. Clinical features and outcome of solid pseudopapillary neoplasm: differences between adults and children. Arch Surg 2008;143:1218-21. doi: 10.1001/archsurg.143.12.1218. 
37. Uppin SG, Hui M, Thumma V, Challa S, Uppin MS, Bheerappa N, et al. Solid-pseudopapillary neoplasm of the pancreas: A clinicopathological and immunohistochemical study of 33 cases from a single institution in Southern India. Indian J Pathol Microbiol 2015;58:163-9. doi: 10.4103/0377-4929.155305.

38. Niu ZXW, C.L, Zhao WH,Tian MM, Sun LP, Li YH, et al. The histological origin of solid-pseudopapillary neoplasm of the pancreas. Open Gastroenterol J 2009;3.

39. Notohara K, Hamazaki S, Tsukayama C, Nakamoto S, Kawabata K, Mizobuchi K, et al. Solid-pseudopapillary tumor of the pancreas: immunohistochemical localization of neuroendocrine markers and CD10. Am J Surg Pathol 2000;24:1361-71.

40. Chen C, Jing W, Gulati P, Vargas H, French SW. Melanocytic differentiation in a solid pseudopapillary tumor of the pancreas. J Gastroenterol 2004;39:579-83.

41. Yang F, Jin C, Long J, Yu XJ, Xu J, Di Y, et al. Solid pseudopapillary tumor of the pancreas: a case series of 26 consecutive patients. Am J Surg 2009;198:210-5. doi: 10.1016/j.amjsurg.2008.07.062.

42. Guo N, Zhou QB, Chen RF, Zou SQ, Li ZH, Lin Q, et al. Diagnosis and surgical treatment of solid pseudopapillary neoplasm of the pancreas: analysis of 24 cases. Can J Surg 2011;54:368-74. doi: 10.1503/cjs.011810.

43. Zhang H, Liang TB, Wang WL, Shen Y, Ren GP, Zheng SS. Diagnosis and treatment of solid-pseudopapillary tumor of the pancreas. Hepatobiliary Pancreat Dis Int 2006;5:454-8.

44. Vassos N, Agaimy A, Klein P, Hohenberger W, Croner RS. Solid-pseudopapillary neoplasm (SPN) of the pancreas: case series and literature review on an enigmatic entity. Int JClin Exp Pathol 2013;6:1051-9. doi: 10.1016/j.pan.2014.05.556 